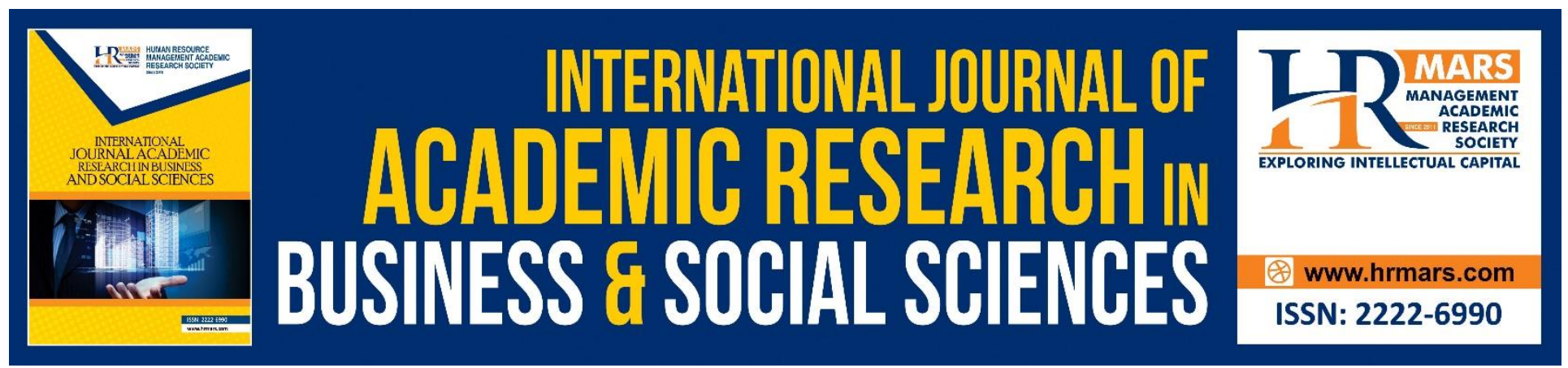

\title{
Evolution in Fashion Retail: Comparing Fashion Specialty Store and Department Store in Malaysia
}

Aida Shaari, Tan Teck Hong

To Link this Article: http://dx.doi.org/10.6007/IJARBSS/v8-i9/4871

DOI: $\quad 10.6007 /$ IJARBSS/v8-i9/4871

Received: 17 August 2018, Revised: 11 Sept 2018, Accepted: 29 Sept 2018

Published Online: 02 October 2018

In-Text Citation: (Shaari \& Hong, 2018)

To Cite this Article: Shaari, A., \& Hong, T. T. (2018). Evolution in Fashion Retail: Comparing Fashion Specialty Store and Department Store in Malaysia. International Journal of Academic Research in Business and Social Sciences, 8(9), 1910-1918.

\section{Copyright: (C) 2018 The Author(s)}

Published by Human Resource Management Academic Research Society (www.hrmars.com)

This article is published under the Creative Commons Attribution (CC BY 4.0) license. Anyone may reproduce, distribute, translate and create derivative works of this article (for both commercial and non-commercial purposes), subject to full attribution to the original publication and authors. The full terms of this license may be seen

at: http://creativecommons.org/licences/by/4.0/legalcode

Vol. 8, No. 9, September 2018, Pg. 1910 - 1918

Full Terms \& Conditions of access and use can be found at http://hrmars.com/index.php/pages/detail/publication-ethics 


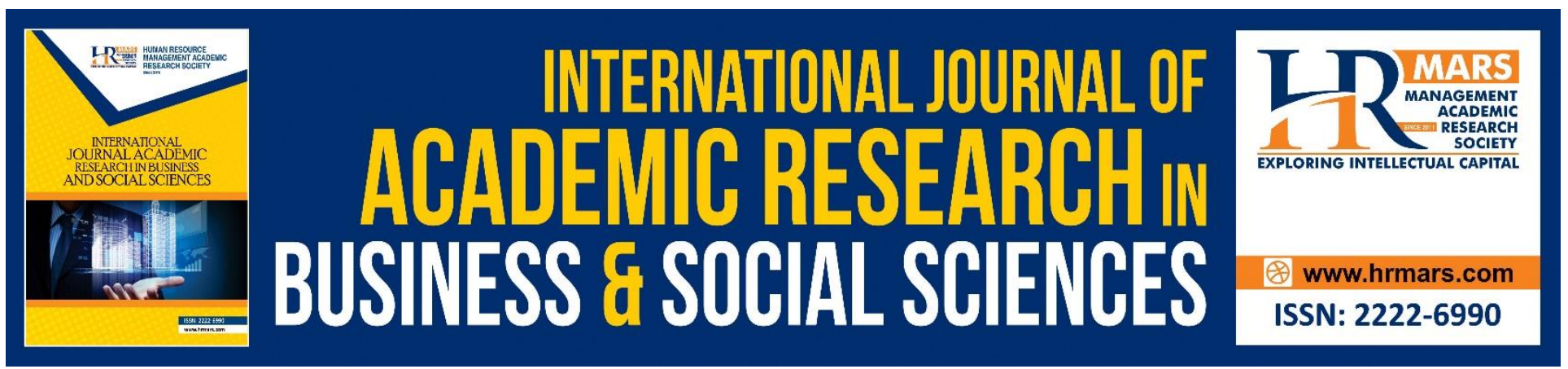

\title{
Evolution in Fashion Retail: Comparing Fashion Specialty Store and Department Store in Malaysia
}

\author{
Aida Shaari, Tan Teck Hong
}

Faculty of Business and Technology, Unitar International University, Kelana Jaya, Selangor, Malaysia

\begin{abstract}
The purpose of this paper is to explore how the evolution in retail landscape had affected the growth of fashion retail and had ignited the changes in customer preference on types of retail outlets to patronage when shopping for their fashion items. The focus is on two types of fashion retail business formats in Malaysia; the fashion specialty stores and the department stores which their respective business trends were seen growing at the opposite directions in the recent years globally. This paper will discuss the issues and trends faced by these two retail formats that led to the rapid sales growth of the fashion specialty stores and the declining trend suffered by the department stores.
\end{abstract}

Keywords: Fashion Retail, Specialty Store, Department Store, Retail Store Format.

\section{Introduction}

Retail is one of the most important sectors in Malaysian economy. Fashion retail is one of the major segments that contributes to the rapid expansion of retail sector in Malaysia. Improvement in education and income level of Malaysians and supported by the borderless information flow from the internet had advanced the Malaysian fashion industry to the next level. The changing trends in fashion has made Malaysian fashion consumers to demand for more, not only on the merchandise but also the preference on where to buy their fashion items.

Modern fashion retail together with the birth of internet had seen the changes from shopping for fashion items in the traditional retail outlets such as the department stores at shopping malls to virtual retail outlets through on-line shopping. Rapid growth of on-line shopping preference due to the convenience it offers to the consumers in terms of assortments, price and hustle free shopping had endangered the traditional way of shopping where customers must be present at respective retail outlets to buy their fashion items.

The traditional retail outlets or brick and mortar retail outlets also had gone through changes in consumer preference especially that involves customers patronage satisfaction while shopping in the outlets. This changes in patronage satisfaction had led to changes in preference of types of retail store format to shop for fashion items. 
INTERNATIONAL JOURNAL OF ACADEMIC RESEARCH IN BUSINESS AND SOCIAL SCIENCES

Vol. 8, No. 9, Sept. 2018, E-ISSN: 2222-6990 @ 2018 HRMARS

\section{Evolution of Retail Landscape in Malaysia}

Modernization and globalization have revolutionized the retail industry in Malaysia, and the shopping preference of Malaysian customers. It has changed the retail ambience from unorganized retailing which consist of small local grocery shops, hand cart and pavement vendors at wet markets and night markets, to organized retailing which consist of licensed retailers operating chains of convenience stores, modern supermarkets, departmental stores and hypermarkets. The advancement of information technology and the birth of internet had created online shopping, a new breed of retail format apart from the traditional brick and mortar concept of retail outlets.

Online shopping had given customers wider choice of shopping experience, thus had narrowed down the market for traditional brick and mortar retail format. Therefore, to stay competitive, retailers need to find ways to become more customer oriented and to deliver better customer value to increase consumer purchase intention and customer retention.

When the former Malaysian Prime Minister, Tun Dr. Mahathir Mohamad wanted to modernize the Malaysian retail industry in the middle of 1980s, many department stores started to emerge in Malaysia such as Jaya Jusco Stores Sdn Bhd (currently known as Aeon Co (M) Bhd), Hankyu Jaya, Parkson and Sogo. These are examples of organized retailers selling fashion items ranging from apparels, cosmetics, handbags and footwear. These department store models counted on the efficiency of a one-stop shopping experience where customers can buy everything from head to toe under one roof plus shopping for non-fashion items such as household items, home appliances and even car accessories and hardware items under one roof.

Malaysia entering the $21^{\text {st }}$ century with dynamic economic growth had transformed Malaysia from low income nation to middle income nation. According to data from Malaysian Economic Planning unit, household with income above RM5,000 a month has grown to 45.1 percent in 2014 compared to 6.7 percent in 1995 . Higher disposable income enables high income Malaysians to be more selective and demanding for finest brand and uniquely exquisite shopping experience. This trend had seen high end retailers with department store formats entering Malaysia such as Debenhams, Mark and Spencer and Robinson \& Co.

Today's Malaysian fashion retail environment is looking into another type of retail format that is seen to be in competition with departmental stores which is the specialty store format. Uniqlo, the Japanese casual wear designer, manufacturer and retailer had opened their first outlet in Malaysia in 2010. The success of Uniqlo in Malaysia had seen other fashion specialty stores entering the Malaysian market, such as Cotton On, H\&M, Zara, and Dorothy Perkins.

\section{Retail Store Format: Department Store and Specialty Store}

Department stores is the retail store format where everything is sold under one roof including non-fashion items such as house hold and home furnishing items. It carries a wide variety of product lines, each operated as separate department managed by specialist buyers or merchandisers. They offer limited-service which provide sales assistance because they carry more shopping goods about which customers need information (Kotler \& Armstrong, 2012). Examples of department store retailers in Malaysia are Parkson, Aeon and Sogo.

Specialty stores on the other hand is a retail format that carry narrow product lines with deep assortment within those lines such as apparel stores, sporting-goods stores, furniture stores and book 
INTERNATIONAL JOURNAL OF ACADEMIC RESEARCH IN BUSINESS AND SOCIAL SCIENCES

Vol. 8, No. 9, Sept. 2018, E-ISSN: 2222-6990 @ 2018 HRMARS

stores. They focus on specific product lines and segment by utilizing market segmentation, market targeting and product specialization. Mostly, their service level is self-service which customers are to perform their own locate-compare-select process in finding their merchandise (Kotler \& Armstrong, 2012). Examples of specialty store retailers in Malaysia are Uniqlo, H\&M, Seng Heng and MPH Bookstores.

\section{Trends in Fashion Retail}

Department stores, being one of the major fashion retail outlets applying the retail format which focus on customer convenience by having everything under one roof or one-stop-shopping. This retail format had made department stores as the crowd puller of a shopping mall; hence they are the anchor tenants of many shopping malls. Many fashion brands, emerging and established brands, were using department stores to start and expand their businesses such as Bonia Group, Padini Group and various branded cosmetic brands. This however, is making department store to become very undifferentiated and has no self-identification. 'Everything under one roof' may not be the preferred business model for fashion retail in present days as it simply means carrying many product lines and fashion brands in separate departments in their outlets. This had made them not able to express the fashion sense needed by new fashion trend followers because of the limited space provided for each product lines and brands. For example, hand bags, shoes and accessories are in other departments and are not displayed together with apparels.

Specialty stores on the other hand, such as Uniqlo adopted a set of strategies from American retailer The Gap, known as 'SPA' (for specialty-store/retailer of private-label apparel), meaning that they would produce their own clothing and sell it exclusively. These specialty stores format, is more customized and able to differentiate themselves by style. Consumers will choose them according to the image and style they carry, therefore, they are serving into a more niche market. Most of the SPA retailers like H\&M, Zara, Gap, Uniqlo and few others are implementing the most current business model in fashion retail called fast-fashion. Caro and Albeniz (2014) defined fast fashion as a business model that combines three elements: (i) Quick response; (ii) Frequent assortment changes; and (iii) Fashionable designs at affordable prices.

All these fashion specialty stores have common criteria which are: they are specialty apparel retailers with brick $\&$ mortar stores and some online presence and they are not 'haute couture' or trendsetters but rather fashion followers that target the mid-to-low price range. According to Barnes and Gaynor (2006), fashion-conscious consumers were exposed to exclusive designs and styles inspired from runways, as such, retailers such as Zara, H\&M, Mango, New Look, and Top Shop were adopting such designs rapidly to attract consumers and introduce interpretations of the runway designs to the stores in a minimum of three to five weeks. 
INTERNATIONAL JOURNAL OF ACADEMIC RESEARCH IN BUSINESS AND SOCIAL SCIENCES

Vol. 8, No. 9, Sept. 2018, E-ISSN: 2222-6990 @ 2018 HRMARS

\section{Issues in Fashion Retail}

This new business model of fashion specialty store is proven to be successful and had taken the fashion industry by storm, thus had given the impact in terms of sales performance of the retailers. Sales performance of some of the major retailers had shown impressive growth in specialty stores and constant declining trend in department stores, which can be translated as higher customers support to specialty stores. Sales trend is the major indicator of the changing customer preferences in their choice of retail outlets to shop for the fashion goods.

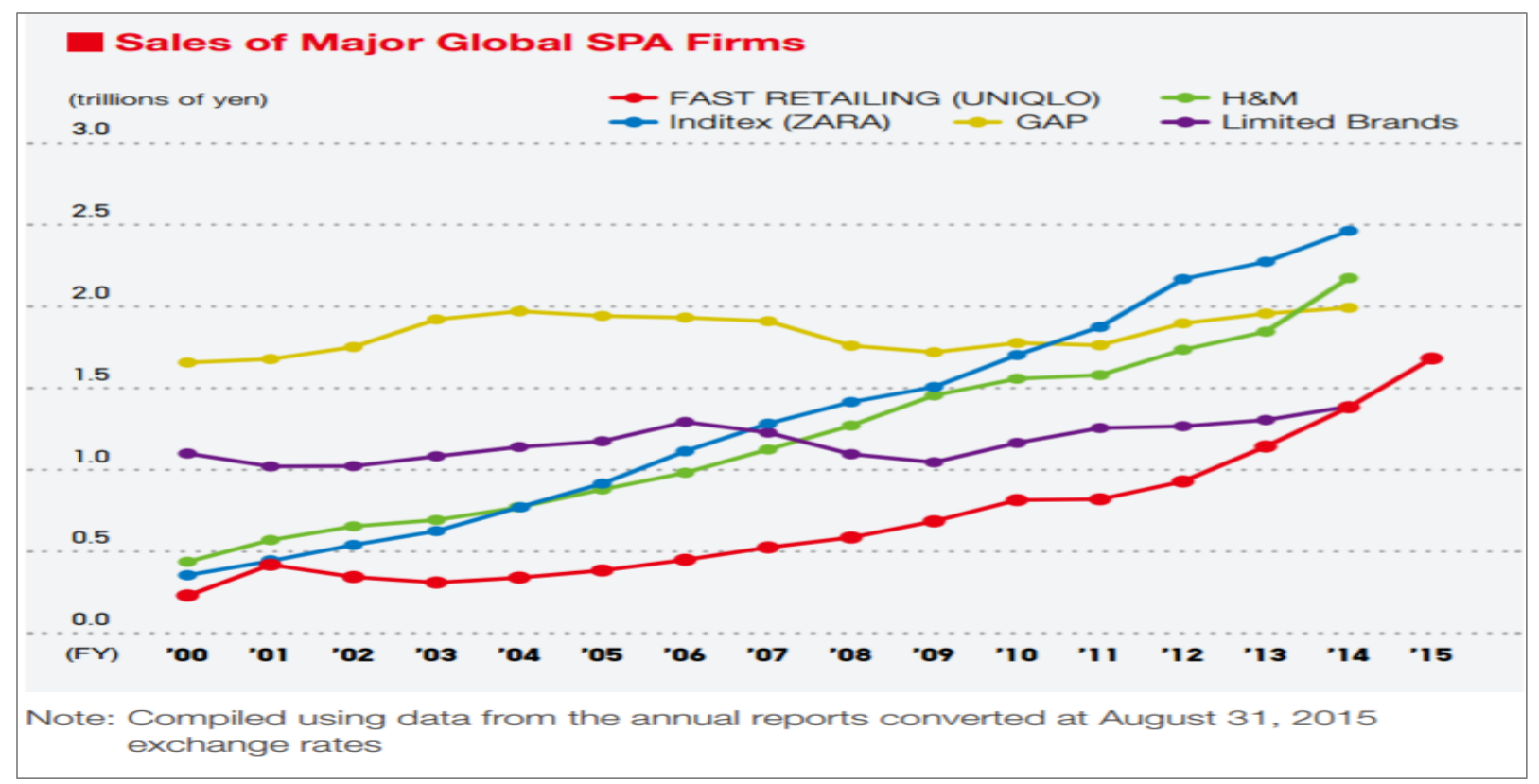

Figure 1: Sales Data for SPA Firms

Source: http://www.fastretailing.com

Specialty store retailers, such as Uniqlo, H\&M, Zara and GAP had recorded tremendous sales growth especially starting from 2011 onwards as shown in Figure 1 above. In addition, Table 1 shows the industry ranking of these retailers and the respective retailers' sales growth from 2016 to 2017 or 2018. Zara, a Spanish fast fashion retailer who tops the ranking had shown an impressive 33 percent growth in two years from 2016 to 2018 while H\&M recorder 14.8 percent growth from 2015 to 2017. 
INTERNATIONAL JOURNAL OF ACADEMIC RESEARCH IN BUSINESS AND SOCIAL SCIENCES Vol. 8, No. 9, Sept. 2018, E-ISSN: 2222-6990 @ 2018 HRMARS

Table 1: Industry Ranking for Apparel Retailers

\begin{tabular}{|c|c|c|c|c|c|}
\hline \multicolumn{4}{|l|}{ I Industry Ranking } & \multicolumn{2}{|c|}{$\begin{array}{l}\text { Last Updated: } 2016.12 .09 \\
\text { to Japanese page }\end{array}$} \\
\hline \multicolumn{6}{|c|}{ Major Global Apparel Manufacturer and Retailer } \\
\hline $\begin{array}{l}\text { Company Name } \\
\text { (Flagship Brand) }\end{array}$ & Country & $\begin{array}{c}\text { End of } \\
\text { Fiscal Year }\end{array}$ & $\begin{array}{c}\text { Sales } \\
\text { (Trillion of } \\
\text { yen) }\end{array}$ & $\begin{array}{l}\text { Sales } \\
\text { (Billions } \\
\text { of dollar) }\end{array}$ & $\begin{array}{l}\text { Change (\%) } \\
\text { (local base) }\end{array}$ \\
\hline INDITEX (ZARA) & Spain & Jan. 2016 & 2.40 & 23.27 & +15.4 \\
\hline Hennes \& Mauritz & Sweden & Nov. 2015 & 2.18 & 21.17 & +19.4 \\
\hline FAST RETAILING(UNIQLO) & Japan & Aug. 2016 & 1.79 & 17.31 & +6.2 \\
\hline Gap & USA & Jan. 2016 & 1.63 & 15.80 & -3.9 \\
\hline L Brands & USA & Jan. 2016 & 1.25 & 12.15 & +6.1 \\
\hline PVH (Calvin Klein, Tommy Hilfiger) & USA & Jan. 2016 & 0.83 & 8.02 & -2.7 \\
\hline Ralph Lauren & USA & Apr. 2016 & 0.76 & 7.41 & -2.8 \\
\hline NEXT & UK & Jan. 2016 & 0.56 & 5.46 & +4.4 \\
\hline AMERICAN EAGLE OUTFITTERS & USA & Jan. 2016 & 0.36 & 3.52 & +7.3 \\
\hline Abercrombie \& Fitch & USA & Jan. 2016 & 0.36 & 3.52 & -6.0 \\
\hline Esprit & $\begin{array}{l}\text { Hong } \\
\text { Kong }\end{array}$ & Jun. 2016 & 0.24 & 2.29 & -8.4 \\
\hline $\begin{array}{l}\text { tes: Compiled from the annual reports } \\
\text { 'Figures calculated in yen using the }\end{array}$ & companie & ted above. & $\because \because 103.2)$ & & \\
\hline
\end{tabular}

\begin{tabular}{|c|c|c|c|c|c|}
\hline \multicolumn{4}{|l|}{ I Industry Ranking } & \multicolumn{2}{|c|}{$\begin{array}{l}\text { Last Updated: } 2018.05 .11 \\
\text { to Japanese page }\end{array}$} \\
\hline \multicolumn{6}{|c|}{ Major Global Apparel Manufacturer and Retailer } \\
\hline $\begin{array}{l}\text { Company Name } \\
\text { (Flagship Brand) }\end{array}$ & Country & $\begin{array}{l}\text { End of } \\
\text { Fiscal Year }\end{array}$ & $\begin{array}{c}\text { Sales } \\
\text { (Trillion of } \\
\text { yen) }\end{array}$ & $\begin{array}{c}\text { Sales } \\
\text { (Billions } \\
\text { of dollar) }\end{array}$ & $\begin{array}{l}\text { Change (\%) } \\
\text { (local base) }\end{array}$ \\
\hline INDITEX (ZARA) & Spain & Jan. 2018 & 3.33 & 30.97 & +8.7 \\
\hline Hennes \& Mauritz & Sweden & Nov. 2017 & 2.61 & 24.31 & +4.0 \\
\hline FAST RETAILING(UNIQLO) & Japan & Aug. 2017 & 1.86 & 17.34 & +4.2 \\
\hline Gap & USA & Feb. 2018 & 1.70 & 15.86 & +2.2 \\
\hline Limited Brands & USA & Feb. 2018 & 1.36 & 12.63 & +0.5 \\
\hline PVH (Calvin Klein, Tommy Hilfiger) & USA & Feb. 2018 & 0.96 & 8.91 & +8.7 \\
\hline Ralph Lauren & USA & Apr. 2017 & 0.71 & 6.65 & -10.2 \\
\hline NEXT & UK & Jan. 2018 & 0.61 & 5.64 & -1.0 \\
\hline AMERICAN EAGLE OUTFITTERS & USA & Feb. 2018 & 0.41 & 3.80 & +5.1 \\
\hline Abercrombie \& Fitch & USA & Feb. 2018 & 0.38 & 3.49 & +5.0 \\
\hline Esprit & \begin{tabular}{|l} 
Hong \\
Kong
\end{tabular} & Jun. 2017 & 0.22 & 2.04 & -10.4 \\
\hline
\end{tabular}

Source: http://www.fastretailing.com

On the other hand, department stores sales performance is moving into the opposite directions as summarized in Table 2. Macy's Inc. one of major department stores in USA operates about 870 stores in 45 states in USA including the District of Columbia, Guam and Puerto Rico, recorded fluctuating sales growth from USD28.1 billion in 2014, gradually decreased in 2015 and 2016 and plummeted to USD24.8 in 2017 (Macy's Inc. Annual Reports 2014 to 2017). In United Kingdom, Mark \& Spencer is one of the leading department stores with 1382 stores worldwide. They are UK's largest clothing retailer by value and have market-leading positions in womenswear, lingerie and menswear. The Group clothing and home business had recorded $£ 4.1$ billion gross sales in 2014 and had constantly reduced around 2.5 percent annually from 2014 to 2017. In 2015, about 0.7 million less customers patronizing their stores compared to 2014 (M\&S Annual Reports 2014 and 2015).

In Asia, Parkson Retail Group Limited established in Republic of China and is one of the few nationwide department store chain operators in China and other Asian countries using 'Parkson' as brand name. Parkson sales proceed continually at negative growth from RMB16.7 billion in 2014 to RMB16.6 billion in 2015 and plummeted to RMB12.9 billion in 2017 (Parkson Retail Group Limited Annual Reports 2014 to 2017).

Table 2: Department Store Sales Performance

\begin{tabular}{c|c|cccc}
\hline Retailer & Country & $\begin{array}{c}\mathbf{2 0 1 4} \\
\text { (Billion) }\end{array}$ & $\begin{array}{c}\mathbf{2 0 1 5} \\
\text { (Billion) }\end{array}$ & $\begin{array}{c}\mathbf{2 0 1 6} \\
\text { (Billion) }\end{array}$ & $\begin{array}{c}\mathbf{2 0 1 7} \\
\text { (Billion) }\end{array}$ \\
\hline Macy & USA & USD28.1 & USD27.1 & USD25.8 & USD24.8 \\
Mark \& Spencer & UK & $£ 4.1$ & $£ 4.0$ & $£ 3.9$ & $£ 3.8$ \\
Parkson & China & RMB16.7 & RMB15.6 & RMB13.4 & RMB12.9
\end{tabular}

Source: Respective Companies' Annual Reports 2014, 2015, 2016 and 2017 
INTERNATIONAL JOURNAL OF ACADEMIC RESEARCH IN BUSINESS AND SOCIAL SCIENCES Vol. 8, No. 9, Sept. 2018, E-ISSN: 2222-6990 @ 2018 HRMARS

The changing customer preference on fashion items towards fast fashion that currently implemented by the big players of fashion specialty store retailers had taken its toll on department stores. Rapid business expansion of these fast fashion specialty stores in Malaysian market had influenced some other brands, though some may not fit as fast fashion retailers, to change their business model and becoming specialty store retailers and no longer depending on department stores to expend their business.

Brands like Padini, Bonia, and sports items retailer such as Royal Sporting House and cosmetics brands like Clinique were previously depending on the expansion plan of department store retailers to expand their businesses. Padini Group for instance, owns products carried under the following brand names; Vincci, Vincci Accessories, Tizio, Padini Authentics, PDI, Padini, Seed, Miki, and P\&Co are operating under three retail format which are free-standing stores or independent retail outlet, consignment counters in department stores and franchise stores. The group also had established their own multi brand specialty store called Padini Concept Store. Table 3 shows a snapshot of the Group's retail network, broken down according to their brands, and markets. It shows that the Group has slowly reducing their consignment counters which operates in department stores and shows the rapid expansion of Padini Concept Stores in Malaysia.

Table 3: Padini Group Retail Network

\begin{tabular}{|c|c|c|c|}
\hline Brands - Domestic Market & As at 30.6.2013 & As at 30.6.2014 & As at 30.6.2015 \\
\hline $\begin{array}{l}\text { Vincci, Vincci+, Vincci Accessories } \\
\text { Free-standing stores } \\
\text { Consignment counters } \\
\text { Franchise stores }\end{array}$ & $\begin{array}{c}17 \\
1 \\
14\end{array}$ & $\begin{array}{c}16 \\
1 \\
13\end{array}$ & $\begin{array}{c}27 \\
1 \\
-\end{array}$ \\
\hline $\begin{array}{l}\text { Seed } \\
\text { Free-standing stores } \\
\text { Consignment counters }\end{array}$ & $\begin{array}{c}3 \\
55\end{array}$ & $\begin{array}{c}2 \\
48 \\
\end{array}$ & $\begin{array}{c}1 \\
42 \\
\end{array}$ \\
\hline $\begin{array}{l}\text { Padini Authentics } \\
\text { Free-standing stores } \\
\text { Consignment counters }\end{array}$ & $\begin{array}{c}8 \\
28\end{array}$ & $\begin{array}{c}7 \\
27\end{array}$ & $\begin{array}{c}5 \\
25\end{array}$ \\
\hline $\begin{array}{l}\text { PDI } \\
\text { Free-standing stores } \\
\text { Franchise stores }\end{array}$ & $\begin{array}{c}13 \\
1\end{array}$ & $\begin{array}{c}13 \\
1\end{array}$ & $\begin{array}{l}14 \\
-\end{array}$ \\
\hline $\begin{array}{l}\text { Padini } \\
\text { Free-standing stores } \\
\text { Consignment counters }\end{array}$ & $\begin{array}{c}2 \\
37\end{array}$ & $\begin{array}{c}2 \\
34\end{array}$ & $\begin{array}{c}1 \\
28\end{array}$ \\
\hline $\begin{array}{l}\text { P\&Co } \\
\text { Free-standing stores }\end{array}$ & 1 & 1 & - \\
\hline $\begin{array}{l}\text { Miki Kids } \\
\text { Consignment counters }\end{array}$ & 29 & 29 & 25 \\
\hline $\begin{array}{l}\text { Miki Baby } \\
\text { Consignment counters }\end{array}$ & - & 28 & 24 \\
\hline $\begin{array}{l}\text { Tizio } \\
\text { Free-standing stores }\end{array}$ & 2 & 3 & 4 \\
\hline $\begin{array}{l}\text { Brands Outlet } \\
\text { Free-standing stores }\end{array}$ & 20 & 27 & 31 \\
\hline $\begin{array}{l}\text { Multi-brands } \\
\text { Free-standing stores * }\end{array}$ & 25 & 29 & 34 \\
\hline Total & 256 & 281 & 262 \\
\hline
\end{tabular}

\section{Source: Padini Holding Berhad Annual Report 2015}

Specialty store retailers in Malaysia recorded impressive sales growth and business expansions in Malaysian market. Hennes \& Mauritz AB for instance operating thirty H\&M outlets in Malaysia has 
INTERNATIONAL JOURNAL OF ACADEMIC RESEARCH IN BUSINESS AND SOCIAL SCIENCES Vol. 8, No. 9, Sept. 2018, E-ISSN: 2222-6990 @ 2018 HRMARS

recorded impressive sales growth of RM231 million in 2013 to RM365 million in 2014 (growth of 158 percent) and RM445 million in 2015 (growth of 122 percent). The Padini Group, a Malaysian local company recorded sales growth from RM789 million in 2013 to RM866 million in 2014 and further increased to RM978 million in 2015.

Department stores retailers on the other hand are suffering from either slow or declining revenue growth in recent years. For example, Parkson with 42 department stores in Malaysia reported RM11.9 million sales in 2015, slight increased to RM12.0 million in 2016 but plummet to RM11.6 million in 2017 (Parkson Holding Berhad Annual report). Aeon, the Japanese retailer that operates 34 department stores in Malaysia had recorded RM3.28 billion sales in 2015, slight increase to RM3.4 billion in 2016 and remain at RM3.4 billion in 2017 (Aeon Co (M) Bhd Annual report 2017). This sales performance recorded by Aeon, although shown slight growth pattern, is still considered not impressive as the sales reported is inclusive of the new outlets sales, which shows that their same store performance is particularly at a declining trend.

\section{Conclusion and Future Agenda}

The rapid sales growth and business expansion of specialty stores and fluctuating and declining business performance of some major department store retailers around the globe shows that there are changing trends in consumer preference towards retail format when shopping for fashion items. The business environment in general is facing rapid changes and challenges to stay ahead of competition. The marketplace is saturated with similar products and copycat business strategies, making the market to become highly complex with more sophisticated and well-informed consumers.

Fashion retail industry had been trying to please all customer segments simultaneously as what had been practiced by the department store retail players. However, the degree of success varies mainly because retailers did not concentrate on specific strategy with regards to customer demand (Lewis \& Hawksley, 1990). This approached proved to be moderately successful. To excel in the highly competitive environment, the fashion industry must cater for their customers' specific needs (North, De Vos and Kotze, 2003).

It seems that customers nowadays, especially young adults, are becoming more conscious about personal image and fashion. For these types of consumers, shopping is an entertaining, pleasure-filled activity that is like an escape. It is important to note that such shoppers are looking for good service standards too. Branding and advertising build brand awareness and purchase predisposition. However, these does not always translate into sales as many purchase decisions are made or influenced on the selling floor itself (Underhill, 1999).

Therefore, it is critical for fashion items retailers to understand the drivers that will influence consumers to patronize their retail outlets. These drivers are factors which presented by the store retail image and image attributes that were decided by respective retail company to put up as their value proposition. Future research should find out whether there are any differences in store retail image carried out by fashion specialty stores compared to department stores that had made the specialty stores becoming the customer preference in this modern fashion industry. This research also will be useful for the department store retailers to understand their drawbacks and to take necessary action to improve their business model. 
INTERNATIONAL JOURNAL OF ACADEMIC RESEARCH IN BUSINESS AND SOCIAL SCIENCES

Vol. 8, No. 9, Sept. 2018, E-ISSN: 2222-6990 (C) 2018 HRMARS

\section{Corresponding Author}

Aida Binti Shaari

Faculty of Business and Technology

UNITAR International University,

Malaysia.

Email: aida@unitar.my

\section{References}

Aeon Co (M0 Bhd Annual Report 2017. Retrieved from http://www.aeonretail.com.my/corporate/investor/annual/

Barnes, L., and Gaynor. L.G (2006). Fast fashioning the supply chain: Shaping the research agenda. Journal of Fashion Marketing and Management 10 (3): 259-71.

Caro, F. \& Martınez-de-Albeniz, V. (2014) Fast Fashion: Business Model Overview and Research Opportunities. Retrieved

from:

http://personal.anderson.ucla.edu/felipe.caro/papers/CaroMartinez-de-

Albeniz2014 BookChapterFastFashion.pdf

H\&M Group Annual report 2017. Retrieved from: https://about.hm.com/en/investors/reports.html

Kotler, P., \& Armstrong, G. (2012), Principles of Marketing, Global edition (15 th ed.). Harlow, England: Pearson.

Lewis, B.R, and Hawksley, A.W (1990). Gaining a competitive advantage in fashion retailing. International journal of retail and distribution marketing, 18 (4), pp 21-32.

Macy's Inc. Annual reports 2014, 2015, 2016 and 2017. Retrieved from: http://www.annualreports.com/Company/macys-inc

M\&S Annual reports $2014 . \quad$ Retrieved from

http://annualreport2014.marksandspencer.com/

M\&S Annual reports 2015. Retrieved from http://annualreport2015.marksandspencer.com/

M\&S Annual reports 2016. Retrieved from http://annualreport2016. marksandspencer.com/

M\&S Annual reports 2017. Retrieved from http://annualreport2017.marksandspencer.com/

North, E.J., De Vos, R.B., Kotze, T. (2003). The importance of apparel product attributes for the female buyers. Journal of family ecology and consumer science, 31, pp 41-51.

Padini Holding Berhad Annual Report 2015. Retrieved at:

http://corporate.padini.com/index.php/corporate/index/investor relations/annual report

Parkson Retail Group Limited Financial reports 2014 to 2017. Retrieved at http://www.parksongroup.com.cn/html en/investor relations/Financial Reports.php

Underhill, P. (1999). Why We Buy: The Science of Shopping. Simon and Schuster, New York, 